\title{
アンサンブル予報を利用した積算予測雨量 精度の不確実性の推定に関する研究 ESTIMATION OF THE UNCERTAINTY OF ACCURACY OF FORECASTED ACCUMULATED RAINFALL USING ENSEMBLE PREDICTION
}

\author{
田原俊彦 1 ・大石哲 2 \\ Toshihiko TAHARA, Satoru OISHI \\ 1学生員 神戸大学大学院 工学研究科市民工学専攻（干657-8501 兵庫県神戸市灘区六甲台町1-1） \\ 2フェロー会員 工博 神戸大学教授 都市安全研究センター（†657-8501 兵庫県神戸市灘区六甲台町1-1）
}

\begin{abstract}
Recently, there has been considerable interest to improve the flood control function of the dams by prior releasing. Carrying out prior releasing has the risk in terms of water utilization. Therefore, it should be taken into consideration that releasing larger amount of water than rain gives water shortage. In this study, we examined the possibility of prior releasing using accumulated rainfall forecasted by Japan Meteorological Agency. Concretely, we investigated that it could estimate the accuracy of forecasted accumulated rainfall based on Global Spectral Model (GSM) by adding the information of spreads calculated by One-week Ensemble Prediction System (WEPS). As a result, we found that the accuracy of forecasted accumulated rainfall based on GSM relates to the spreads calculated by WEPS in case of typhoon. The study results further suggest that it will be possible to improve the flood control function of the dams by prior releasing using forecasted accumulated rainfall.
\end{abstract}

Key Words : dam operation, prior releasing, numerical weather forecast model, ensemble prediction, GSM

\section{1. はじめに}

局地的集中豪雨，台風等による豪雨災害として，河川 水位の上昇による洪水被害が挙げられる. 我が国におい ては，特に河川勾配が急であるため，流入する雨が下流 に短時間で到達することによって水位が急上昇すること が洪水被害を拡大させる要因の一つとなっている．河川 水位の上昇による洪水被害を軽減するためには，河川上 流に位置するダムによる洪水調節が大きな役割の一つを 担う。しかし，近年の気候変動により，既存ダム群の従 来通りの運用だけでは頻発する豪雨災害に対応できなく なりつつある.こうした状況を踏まえ，国土交通省は 2004年に豪雨災害対策緊急アクションプラン1)を策定し た. 豪雨災害対策緊急アクションプランでは，「ダムの 操作ルールは，計画に基づき，洪水調節と利水容量を明 確に区分して管理することが基本」という従来の考えを 改め，「降雨予測技術を活用した事前放流などダムの機 能をより有効に活用できるよう操作ルールを変更」とい う新しい考えが提唱されている，事前放流とは，洪水の
発生を予測した場合に利水の共同事業者に支障を与えな い範囲で，制限水位以下の利水容量などを放流して，治 水容量として一時的に活用する手法である. 事前放流に より，近年頻発している計画を上回る洪水（超過洪水） に対して，ダムの治水効果を計画以上に期待できること になる2).

これまで，事前放流に関する研究はいくつか行われ

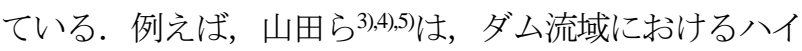
ドログラフの逓減特性から流入量を算出して事前放流量 を決定する手法を提案している。 さらに，北田らのは気 象庁の降水短時間予報を用いた事前放流量の決定手法を 提案しているが，いずれも降雨開始までのリードタイム が短く, 容量が大きいダムでは事前放流を行う時間が十 分に確保できないといった課題がある。また臼谷ら7は， 積算予測雨量に基づいた事前放流方法を提案しているが, 過大な事前放流を行った後の利水容量の回復の一般性が 課題となっている. 事前放流では, 利水者のために確保 している容量を放流するものであることから，一旦放流 した容量を回復させることが大前提となる ${ }^{8)}$.よって, 予測雨量を基に事前放流を行う場合は，予測雨量が実測 


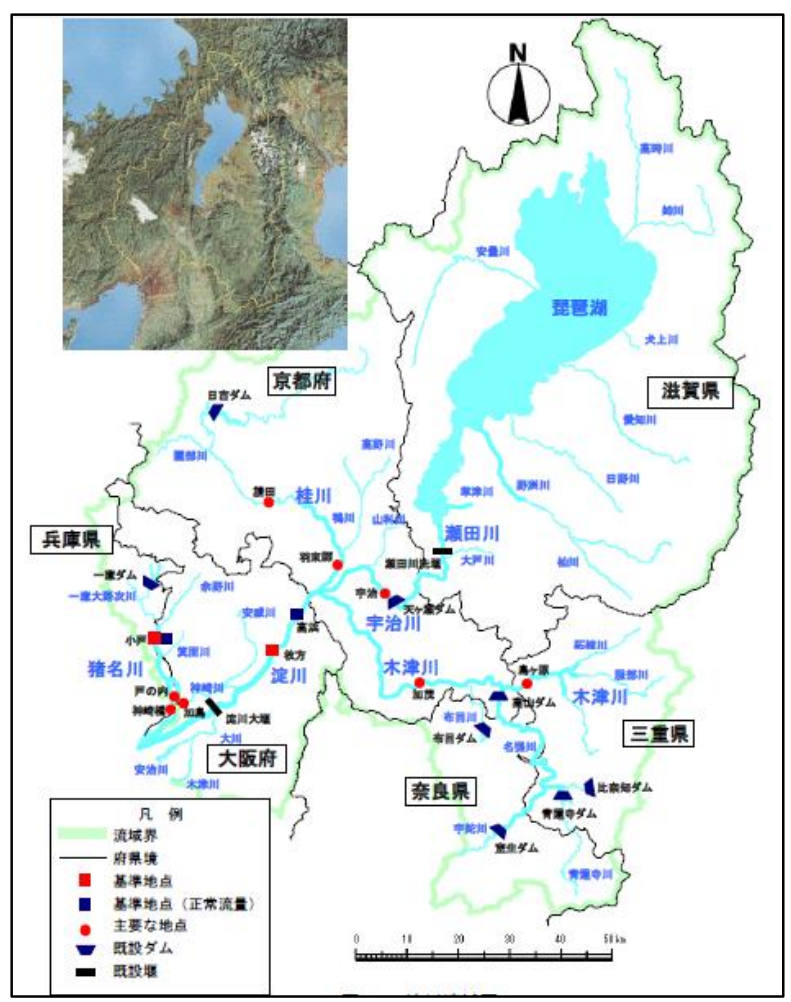

図-1 淀川流域図 ${ }^{9)}$

雨量を大きく上回る予測の空振りを防ぐ必要がある.

そこで本研究では，十分な事前放流を行うために降 雨開始までのリードタイムを確保するという観点と事前 放流を行う上で重要な予測の空振りを防ぐというダム管 理の実務的な観点から, 気象庁から発表される降雨予測 の精度の吟味を行うことで, 降雨予測を用いた事前放流 の可能性について論じた.

\section{2. 研究方法}

\section{（1） 対象となるダム流域}

本研究では淀川水系を対象とした（図-1）。対象とな るダムを表-1に示す，観測雨量は，各ダム流域内にある 雨量観測所を選定し, 水文水質データベース（国土交通 省）とアメダス（気象庁）を用いた. 流域平均雨量は, 算術平均により算出した.

\section{(2) 対象降雨の概要}

本研究では，2008〜2013年に対象領域（北緯30 40， 東経125 145 ）を通過あるいは対象領域内で消滅, 温 帯低気圧化した台風による降雨を対象とした。 なお，台 風が各ダムに最接近した日の一日後までの雨量を台風に よる一連の観測雨量と定義した.

\section{（3）予測雨量データ}

気象庁から発表される今日, 明日, 明後日の天気予 報（短期予報）は，主に全球モデル（GSM）とメソモ
表-1 各ダム流域の雨量観測所

\begin{tabular}{|c|c|}
\hline ダム & 雨量観測所 \\
\hline 日吉ダム & $\begin{array}{l}\text { 広河原, 花雀, 鎌倉, 周山, 京北 } \\
\text { (アメタタス }\end{array}$ \\
\hline 天ヶ瀬ダム & $\begin{array}{llll}\text { 黒津, 瀬田川, 雲井, 大鳥居, 西 } \\
\text { 笠取, 天ヶ瀬, 宮村, 多羅尾, 信 } \\
\text { 楽 (アメダス) }\end{array}$ \\
\hline 室生ダム & 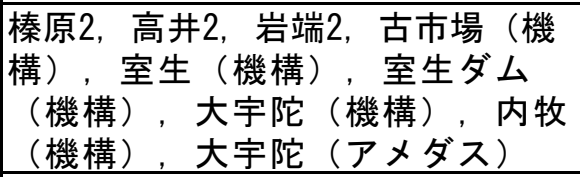 \\
\hline 青蓮寺ダム & $\begin{array}{l}\text { 土屋原（砂），太良路，山粕，香 } \\
\text { 落，国津（機構），青蓮寺ダム }\end{array}$ \\
\hline 比奈知ダム & \begin{tabular}{|l} 
神末, 比奈知, 菅野（機構）， 曽 \\
爾（アメダス）
\end{tabular} \\
\hline 高山ダム & $\begin{array}{l}\text { 尾山2, 名張2, 黒田堂ケ谷, 龍 } \\
\text { 口, 香酔山，䈉間 (機構)，家野 } \\
\text { (機構)，名張 (アメダス) }\end{array}$ \\
\hline 布目ダム & $\begin{array}{c}\text { 針ヶ別所2， 井之市（機構），峰寺 } \\
(\text { 機構），針（アメダス） }\end{array}$ \\
\hline
\end{tabular}

表-2 数值予報モデルの概要

\begin{tabular}{|c|c|c|}
\hline & $\begin{array}{c}\text { GSM } \\
\text { (全球モデル) }\end{array}$ & $\begin{array}{c}\text { WEPS } \\
\text { (週間アンサンブル } \\
\text { 予報) }\end{array}$ \\
\hline 水平解像度 & 約20km & 約60km \\
\hline リードタイム & 84 8時間 & 192時間 \\
\hline 予報時間 & $\begin{array}{c}\text { 1日4回 (6時間間隔) } \\
\text { (UTC:00, 06, 12, 18) }\end{array}$ & $\begin{array}{c}1 \text { 日1回 (6時間間隔) } \\
\text { (UTC:12) }\end{array}$ \\
\hline 出カデータ & $\begin{array}{c}\text { 風向・風速, 気温, 相対湿度, 積算降水 } \\
\text { 量, 全雲量, 海面更正気圧, 地上気圧 }\end{array}$ \\
\hline
\end{tabular}

デル（MSM）が用いられている. 容量の大きいダムに おいて，十分な事前放流を行うために降雨開始までの リードタイムを確保するという観点から, 予報時間が長 いGSMを用いるのが適切であると考えられる.しかし， GSMは決定論的予報であることから予報の不確実性を 考慮することができず, GSMの予測雨量をそのまま事 前放流量の推定に用いるのは利水面から見たリスクがあ る. そこで本研究では, 確率論的予報である週間アンサ ンブル予報（WEPS）から得られるスプレッドなどの情 報を付加することで, GSMの予測雨量の精度をあらか じめ推定することができるのか検討した. アンサンブル 予報とは, 初期值に解析誤差程度のばらつき（摂動）を 与えた複数のアンサンブル初期值を用意し，それぞれに 対して数值予報モデルによる予測を実行することで得ら れた複数の数值予報結果（アンサンブルメンバー予報） のばらつきを統計的に処理することにより「予報の不確 実性」を推定することができる手法である ${ }^{10)}$. GSM と WEPSのデータの概要を表-2に示す. GSMの予測雨量の 精度とWEPSから得られるスプレッドなどに関係性が見 られれば, GSMの予測雨量の精度をあらかじめ推定し， 事前放流を行う上で重要な予測の空振りを防ぐことが可 能になる. そこで, WEPSから対象となるダムに最接近 


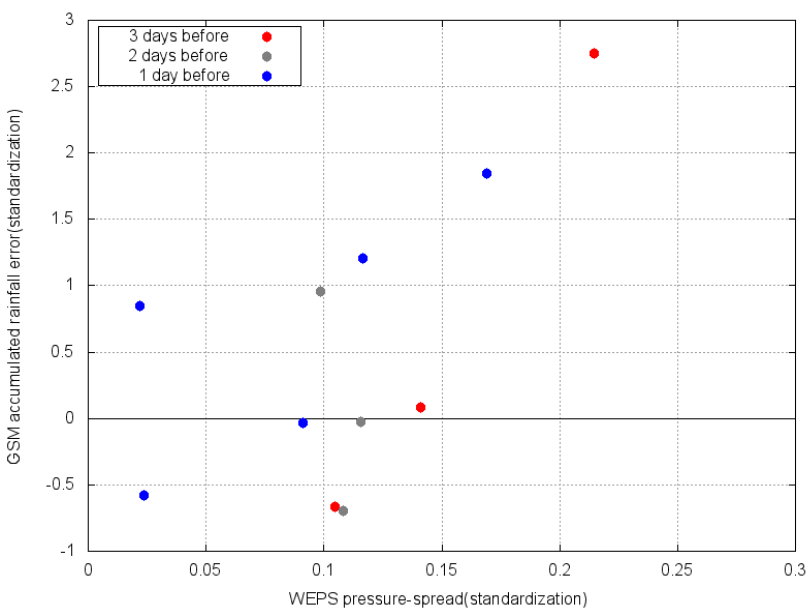

図-2ＧSM積算雨量誤差（標準化）とWEPS気圧スプ レッド（標準化）の関係（日吉ダム）

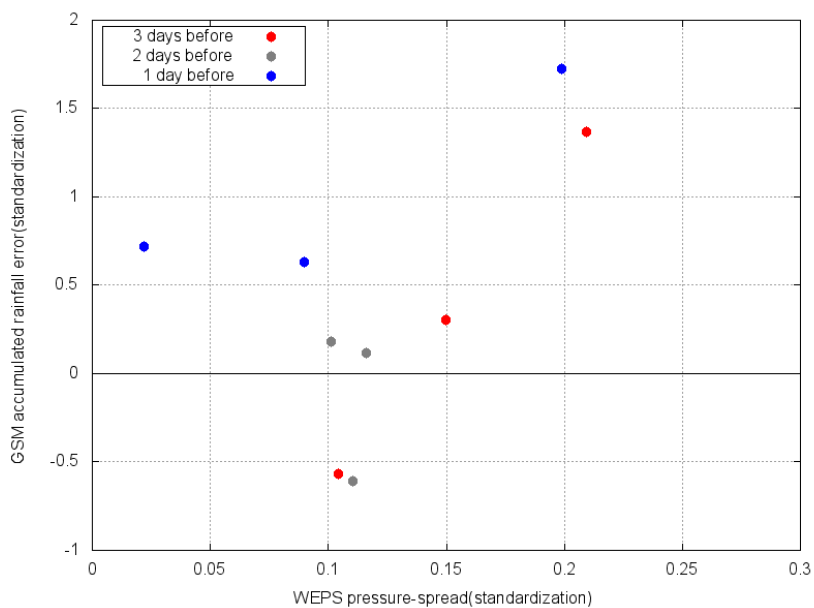

図-3 GSM積算雨量誤差（標準化）とWEPS気圧スプ レッド (標準化) の関係（天ヶ瀬ダム）

した時の, 台風中心の緯度, 経度, 各ダムからの距離, 海面更正気圧，風速，時間のスプレッドとGSMの予測 雨量の精度の関係性，またWEPSの予測雨量のアンサン ブル平均值・中央值と GSM の予測雨量の精度の関係性 を調査することで，これらの情報を組久合わせることで 予測の空振りを防ぐ可能性について検討した.

\section{3. 結果}

\section{（1）日吉ダム}

日吉ダムにおけるGSM積算雨量誤差（標準化）と WEPS気圧スプレッド（標準化）の関係を図-2に示寸. WEPSは1日1回12UTCを初期時間としていることから， GSMも12UTCを初期時間としたデータだけを用いた. GSM積算雨量とWEPS積算雨量は，それぞれリードタイ ムが84時間，192時間で，台風が各ダムに最接近した日 の3日前，2日前，1日前の予報を用いた．また，事前放 流は大雨が予測される場合に検討されると想定されるこ とから，GSM積算雨量が100mm以上となる場合だけを

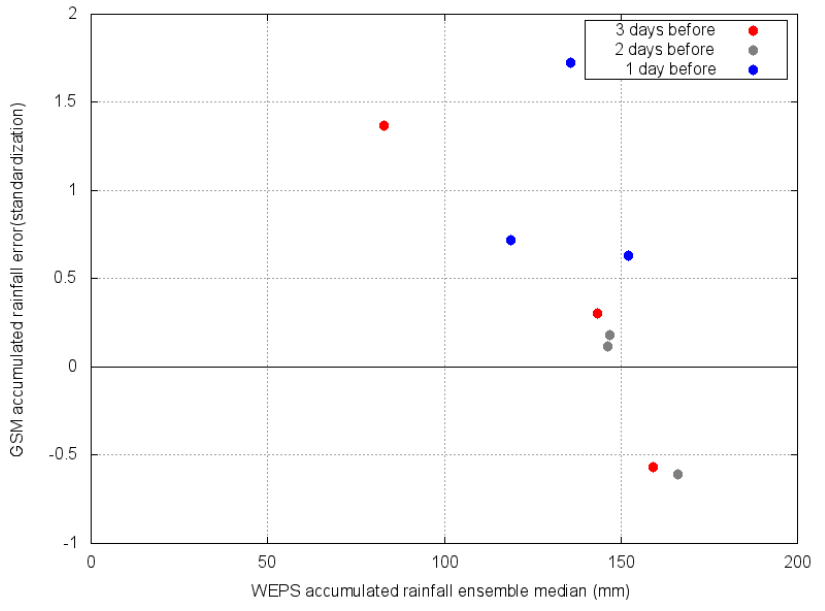

図-4ＧSM積算雨量誤差（標準化）とWEPS積算雨量 アンサンブル中央値の関係（天ヶ瀬ダム）

抽出した。図-2の縦軸は，GSM積算雨量と観測雨量の 差を観測雨量で割り標淮化したものである.よって，正 であれば予測雨量が観測雨量を上回る予測の空振りとな り，事前放流を行う際は，縦軸が正となる場合を防ぐ必 要がある. 図-2の横軸は，台風が日吉ダムに最接近した 時の海面更正気圧（以下，気圧）のスプレッドを，1気 圧（1013hPa） と気圧のアンサンブル平均值の差で割り 標準化したものである，図-2より，日吉ダムにおいて は,GSM積算雨量が過大評価となる事例が多いことがわ かる．よって，日吉ダムでは事前放流は慎重に行うべき であると言える．また図-2より，気圧のスプレッドが 0.15以上と大きい場合にGSM積算雨量が観測雨量を大き く上回っている. 一方, GSM積算雨量誤差（標準化） とWEPS積算雨量アンサンブル平均值には関係性が見ら れなかったので，図は省略する.

以上の検討により，日吉ダムにおいては，気圧スプ レッドが 0.15 以上の場合は予測が大きく空振りする可能 性が高いので，事前放流を行うべきではないとアンサン ブル予報から判断される.

\section{（2）天ヶ瀬ダム}

天ヶ瀬ダムにおけるGSM積算雨量誤差（標準化） WEPS気圧スプレッド（標準化）の関係を図-3に，GSM 積算雨量誤差（標準化）とWEPS積算雨量アンサンブル 中央值の関係を図-4に示す，天ヶ瀬ダムでは，WEPS積 算雨量アンサンブル平均值ではなく，より相関関係が見 られるWEPS積算雨量アンサンブル中央值を用いた．図 -3より，日吉ダムと同様に天ヶ瀬ダムにおいても，気圧 のスプレッドが 0.2 前後と大きい場合にGSM積算雨量が 観測雨量を大きく上回っている．また図-4より，GSM 積算雨量誤差（標準化）とWEPS積算雨量アンサンブル 中央值の関係の相関係数は-0.7で負の相関があった.

以上の検討により，天ヶ瀬ダムにおいては，気圧ス プレッドが 0.20 以上の場合やWEPS積算雨量アンサンブ ル中央值が $150 \mathrm{~mm}$ 以下の場合は，予測が空振りする可 


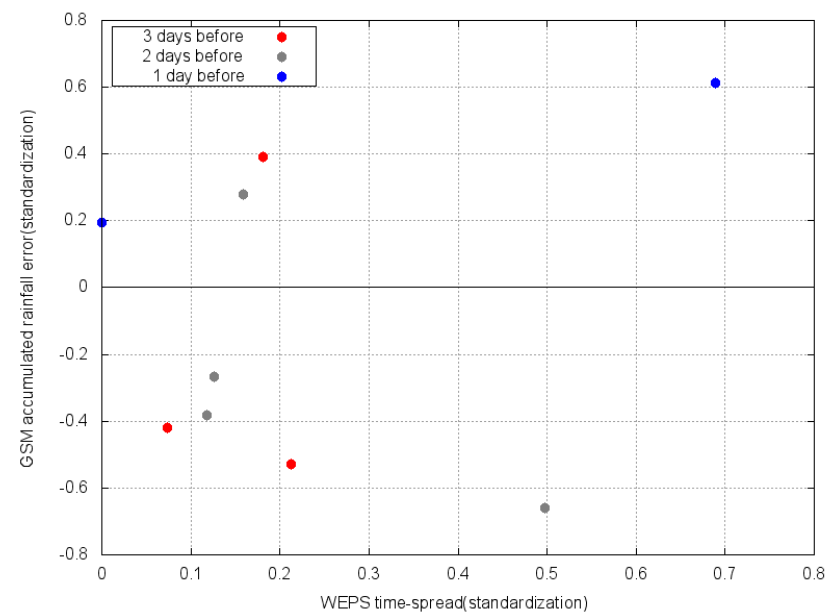

図-5 GSM積算雨量誤差（標準化）とWEPS時間スプ レッド（標準化）の関係（室生ダム）

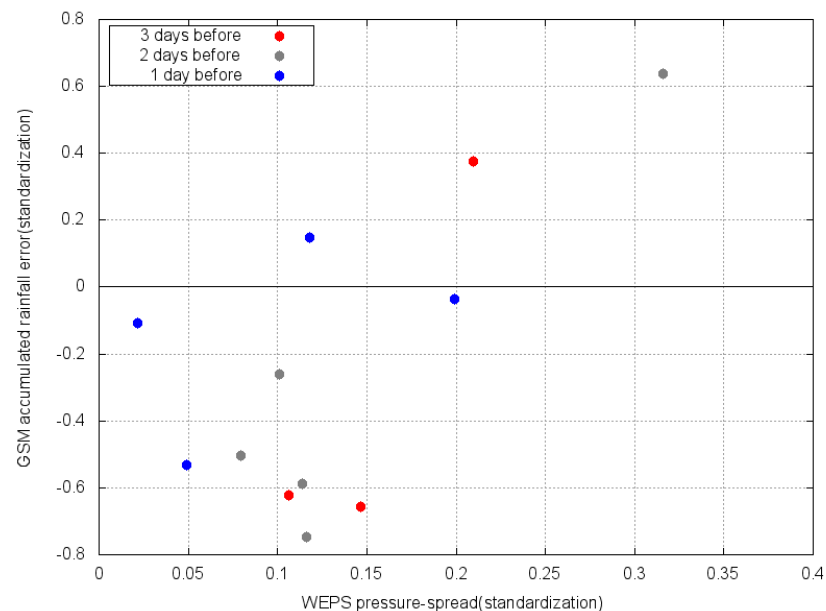

図-7 GSM積算雨量誤差（標準化）とWEPS気圧スプ レッド（標準化）の関係（青蓮寺ダム）

能性が高いので，事前放流を行うべきではないとアンサ ンブル予報から判断される.

\section{（3） 室生ダム}

室生ダムにおけるGSM積算雨量誤差（標準化）と WEPS時間スプレッド（標準化）の関係を図-5に，GSM 積算雨量誤差（標準化）とWEPS積算雨量アンサンブル 平均值の関係を図-6に示す，室生ダムでは，気圧スプ レッドではなく，より関係性が見られる時間スプレッド を用いた．図-5の横軸は，時間のスプレッドを，時間の アンサンブル平均值で割り標準化したものである. 図-5 より，時間のスプレッドが大きくなるにつれてGSM積 算雨量の過大評価の幅が大きくなっていることがわかる。 また図-6より，GSM積算雨量誤差（標準化）とWEPS積 算雨量アンサンブル平均值の関係の相関係数は-0.7で負 の相関があった。

以上の検討により，室生ダムにおいては，時間スプ レッドが 0.50 以上の場合やWEPS積算雨量アンサンブル 平均值が $110 \mathrm{~mm}$ 以下の場合は，予測が空振りする可能 性が高いので，事前放流を行うべきではないとアンサン

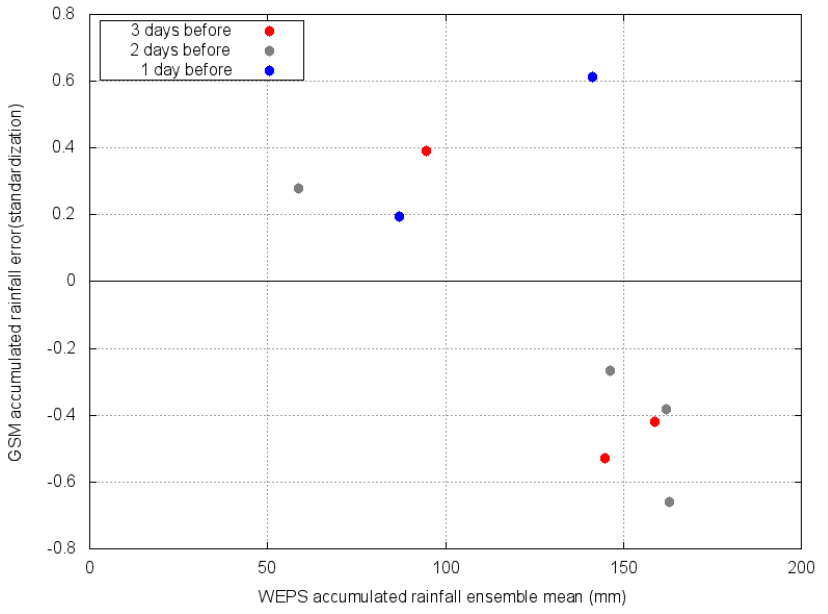

図-6ＧSM積算雨量誤差（標準化）とWEPS積算雨量 アンサンブル平均値の関係（室生ダム）

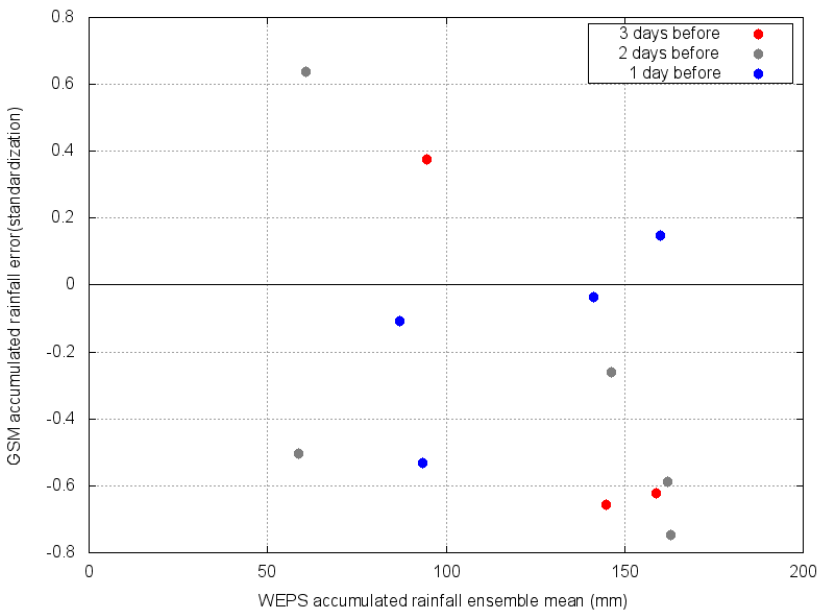

図-8 GSM積算雨量誤差（標準化）とWEPS積算雨量 アンサンブル平均值の関係（青蓮寺ダム）

ブル予報から判断される.

\section{（4）青蓮寺ダム}

青蓮寺ダムにおけるGSM積算雨量誤差（標準化）と WEPS気圧スプレッド（標準化）の関係を図-7に，GSM 積算雨量誤差（標準化）とWEPS積算雨量アンサンブル 平均值の関係を図-8に示す. 図-7, 図-8より，青蓮寺ダ ムにおいては，GSM積算雨量が過小評価となる事例が 多いことがわかる．よって，青蓮寺ダムでは事前放流が 行いやすいと言える. 図-7より，気圧のスプレッドが大 きくなるにつれてGSM積算雨量の過大評価の幅が大き くなっていることがわかる，また図-8より，WEPS積算 雨量アンサンブル平均值が小さくなるとGSM積算雨量 の過大評価の幅が大きくなっている.

以上の検討により，青蓮寺ダムにおいては，気圧ス プレッドが 0.20 以上かつWEPS積算雨量アンサンブル平 均值が100mm以下の場合は，予測が空振りする可能性 が高いので，事前放流を行うべきではないとアンサンブ ル予報から判断される. 


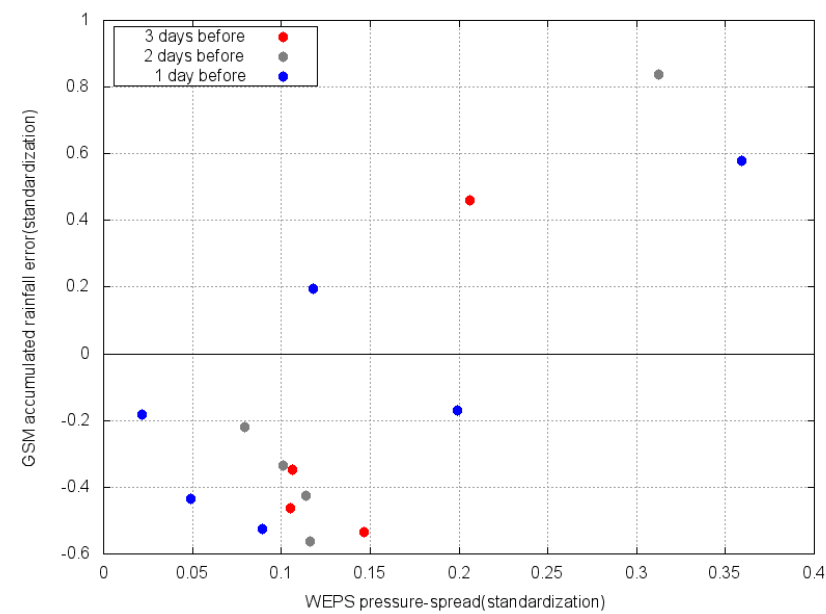

図-9 GSM積算雨量誤差（標準化）とWEPS気圧スプ レッド（標準化）の関係（比奈知ダム）

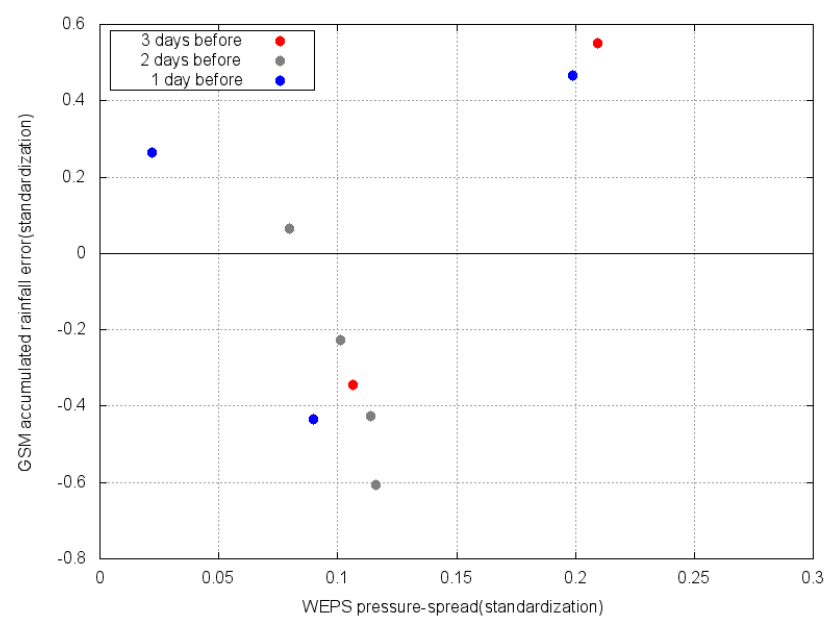

図-11 GSM積算雨量誤差（標準化）とWEPS気圧スプ レッド（標準化）の関係（高山ダム）

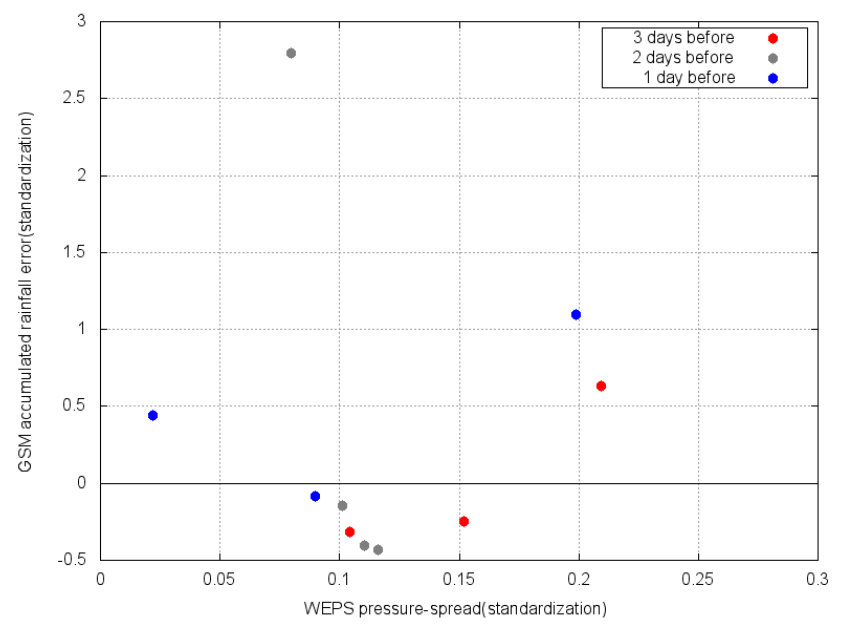

図-13 GSM積算雨量誤差（標準化）とWEPS気圧スプ レッド（標準化）の関係（布目ダム）

\section{（5）比奈知ダム}

比奈知ダムにおけるGSM積算雨量誤差（標準化）と WEPS気圧スプレッド（標準化）の関係を図-9に，GSM 積算雨量誤差（標準化）とWEPS積算雨量アンサンブル

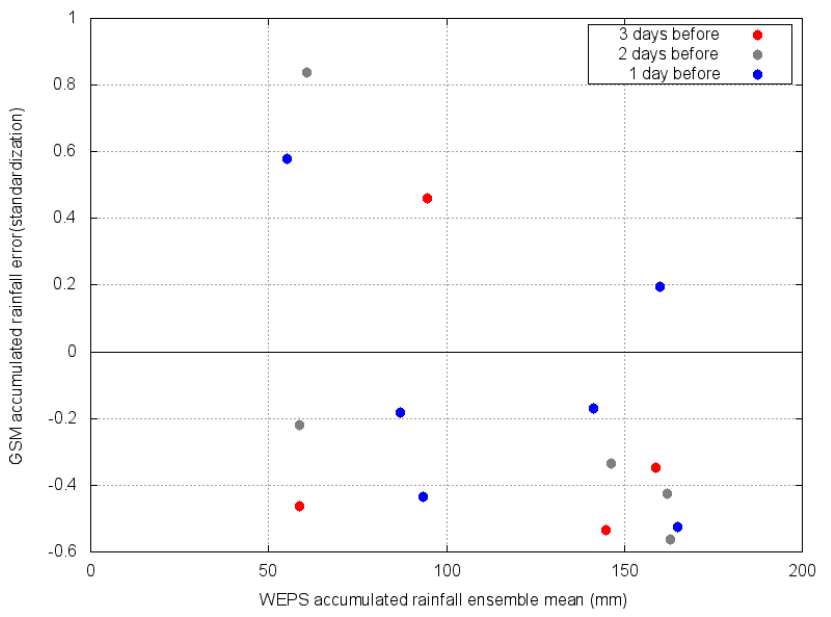

図-10 GSM積算雨量誤差（標準化）とWEPS積算雨量 アンサンブル平均値の関係（比奈知ダム）

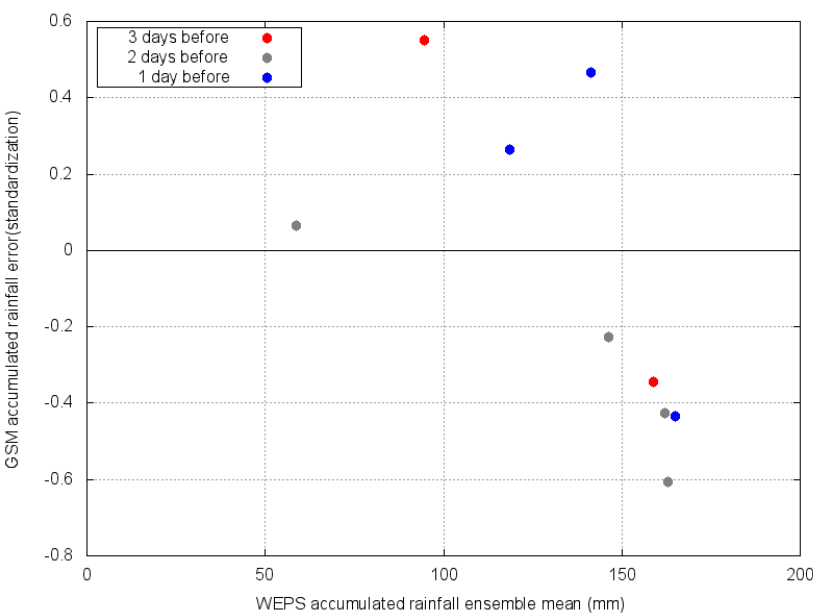

図-12 GSM積算雨量誤差（標準化）とWEPS積算雨量 アンサンブル平均値の関係（高山ダム）

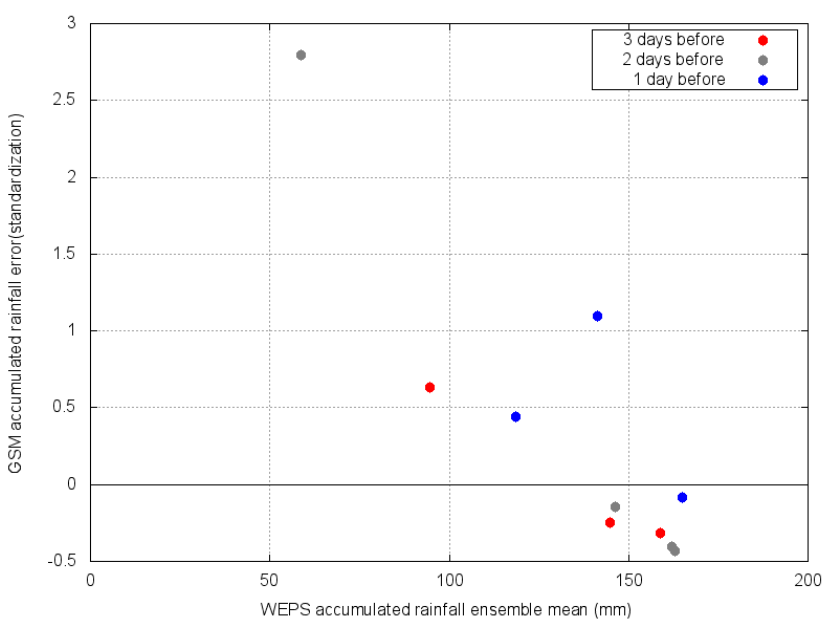

図-14ＧSM積算雨量誤差（標準化）とWEPS積算雨量 アンサンブル平均値の関係（布目ダム）

平均值の関係を図-10に示す．比奈知ダムにおける結果 は，青蓮寺ダムの結果と同じ傾向を示している.

以上の検討により，比奈知ダムにおいては，気圧ス プレッドが 0.20 以上かつWEPS積算雨量アンサンブル平 
均值が100mm以下の場合は, 予測が空振りする可能性 が高いので，事前放流を行うべきではないとアンサンブ ル予報から判断される。

\section{（6） 高山ダム}

高山ダムにおけるGSM積算雨量誤差（標準化）と WEPS気圧スプレッド（標準化）の関係を図-11に, GSM積算雨量誤差（標準化）とWEPS積算雨量アンサン ブル平均值の関係を図-12に示す. 図-11より，気圧スプ レッドが 0.2 前後と大きい場合にGSM積算雨量が観測雨 量を大きく上回っている．また図-12より，GSM積算雨 量誤差（標準化）とWEPS積算雨量アンサンブル平均值 の関係の相関係数は-0.6で負の相関があった.

以上の検討により，高山ダムにおいては，気圧スプ レッドが 0.20 以上の場合やWEPS積算雨量アンサンブル 平均值が $110 \mathrm{~mm}$ 以下の場合は，予測が空振りする可能 性が高いので，事前放流を行うべきではないとアンサン ブル予報から判断される.

\section{（7）布目ダム}

布目ダムにおけるGSM積算雨量誤差（標準化）と WEPS気圧スプレッド（標準化）の関係を図-13に, GSM積算雨量誤差（標準化）とWEPS積算雨量アンサン ブル平均值の関係を図-14に示す．図-13より，GSM積 算雨量誤差 (標準化) とWEPS気圧スプレッド（標準化） には関係性が見られなかった。しかし，図-14よりGSM 積算雨量誤差（標準化）とWEPS積算雨量アンサンブル 平均值の関係の相関係数は-0.9で負の相関があった.

以上の検討により，布目ダムにおいては，WEPS積算 雨量アンサンブル平均值が $140 \mathrm{~mm}$ 以下の場合は，予測 が空振りする可能性が高いので，事前放流を行うべきで はないとアンサンブル予報から判断される.

\section{（8）全体の考察}

本研究では，予測が空振りとなりそうな事例を識別す ることを目的とし，アンサンブル予報から得られる情報 を用いた指標を作成することを試みた，その結果，予測 が空振りとなりそうな事例を識別する指標はダム毎で異 なっていた，その理由として，同じ台風による事例にお いても，ダム流域毎に地形などの影響によって降雨特性 が異なることが挙げられる.よって，ダム毎に予測が空 振りとなりそうな事例を識別する指標を作成することは, 意義があると言える.

また，室生ダムを除く淀川流域における全てのダムに おいて，気圧スプレッドが大きいと予測が空振りとなる 可能性が高いという関係性が見られた。 これは，WEPS による各ダムに最接近した時の台風の発達具合（中心気 圧）のばらつきが大きく予測の不確実性が大きい事例で は，GSM積算雨量精度の不確実も大きくなるというこ とを示している.
さらに, 室生ダムや布目ダムなど淀川流域の多くのダ ムにおいて, WEPS積算雨量アンサンブル平均值（天ヶ 瀬ダムではアンサンブル中央值）とGSM積算雨量誤差 （標準化）には負の相関が見られた. これは，解像度が 低いWEPSで大雨が予測されている事例では, GSMでも 大雨が降りやすい気象場になっていることが原因だと考 えられる.

\section{4. まとめ}

本研究では，十分な事前放流を行うために降雨開始ま でのリードタイムを確保するという観点と事前放流を行 う上で重要な予測の空振りを防ぐというダム管理の実務 的な観点から, 気象庁から発表される降雨予測の精度の 吟味を行うことで，降雨予測を用いた事前放流の可能性 について検討した．その結果，GSMの積算予測雨量の 精度とWEPSから得られるスプレッドや積算予測雨量ア ンサンブル平均值・中央值にはダム毎にある一定の関係 性が見られ，事前放流を行う上で重要な予測の空振りを 防ぐことが可能であることを示唆することができた。

\section{参考文献}

1) 国土交通省 : 豪雨災害対策緊急アクションプラン， 2004.

2) 兵庫県 : 第33回総合治水ワーキングチーム会議 資料3 「予備放流」と「事前放流」について, 2006.

3) 呉修一, 腰塚雄太, 山田正 : ハイドログラフの莪减特性を 用いた流出特性の抽出, 水工学論文集, 第48巻, pp.13-18, 2004.

4) 秋葉雅章, 腰塚雄太, 宮本守, 戸谷英雄, 佐藤直良, 山田 正 : 流出特性に応じたダム放流量の決定とその洪水水位莪 減効果に関する研究，河川技術論文集，第10巻，pp.89-94， 2005.

5) 戸谷英雄，秋葉雅章，宮本守，山田正，吉川秀夫 : ダム流 域における洪水流出特性から可能となる新しい放流方法の 提案，土木学会論文集B，Vol.62，No.1，pp.27-40， 2006.

6) 北田悠星, 菊地慶, 岡部真人, 山田正 : 気象庁の降水短時 間予報を用いて既存のダムの洪水調節機能を向上させる手 法の提案，水工学論文集，第54巻，pp.523-528，2010.

7) 白谷友秀, 中津川誠 : 積算予測雨量に基づいた融雪期にお けるダムの洪水調節機能の向上について，土木学会論文集

B, Vol.66, No.3, pp.268-279, 2010.

8) 財団法人 ダム水源地環境整備センター : 季刊誌リザバー, No.11, 2006.

9) 国土交通省 近畿地方整備局 : 淀川水系河川整備計画, pp.3, 2009.

10) 酒井亮太 : 気象業務の空 気象庁の新しい週間アンサンブ ル予報システム，天気，Vol.55(6)，pp.515-520， 2008.

(2015. 9. 30受付) 